\title{
Organizing interfaces between government institutions and interactive governance
}

\author{
Jurian Edelenbos $\cdot$ Nienke van Schie $\cdot$ Lasse Gerrits
}

Published online: 5 May 2009

(C) The Author(s) 2009. This article is published with open access at Springerlink.com

\begin{abstract}
Initiatives to encourage the involvement of citizens and NGOs in decisionmaking can be seen in a wide variety of countries. Interactive policy-making, citizen panels, citizen charters, new forms of participation and other forms are being used to increase the influence of citizens on decision-making. An important issue in scientific debate is the relationship between citizen participation and existing democratic institutions. The main question for this article therefore is: what are the possibilities and difficulties in creating interconnections between interactive governance and existing democratic institutions? We have conducted an action research project to organize this interconnection between an interactive governance project (Around Arnemuiden, Living with Water) and existing democratic institutions. We describe and evaluate the interface arrangements we created: political, executive, professional, and policy interface. The executive, professional, and policy interfaces turned out to be weak or moderate, while the political interfaces was strong. Executives and professionals are reluctant to actively involve and commit to interactive processes. The organization of the interconnection between interactive processes and existing representative democratic institutions is very difficult and needs constant maintenance.
\end{abstract}

Keywords Democracy - Interactive policy-making · Citizen participation · Governance · Interface · Interconnection

\footnotetext{
J. Edelenbos $(\square) \cdot$ L. Gerrits

Department of Public Administration, Erasmus University Rotterdam, PO Box 1738, 3000 DR

Rotterdam, The Netherlands

e-mail: edelenbos@fsw.eur.nl

L. Gerrits

e-mail: gerrits@fsw.eur.nl

N. van Schie

Department of ESM, Erasmus University Rotterdam, Rotterdam, The Netherlands e-mail: vanschie@fsw.eur.nl
} 


\section{Introduction}

The emergence, development, and effectiveness of governance networks are important topics in the domains dealing with public decision making (cf. Kooiman 1993; Castells 2000; Milward and Provan 2000; Agranoff and McGuire 2003; Sørenson and Torfing 2007). The trend toward governance includes attempts to encourage and stimulate the involvement of stakeholders in decision-making processes. Stakeholder involvement can take many different forms, such as citizen panels, citizen charters, interactive decision making, citizen participation, interactive governance, etc. (see, e.g. McLaverty 2002; Lowndes et al. 2001; Edelenbos 2005).

Experiments in citizen and stakeholder participation have also emerged in the Netherlands (cf. Klijn and Koppenjan 2000; Edelenbos and Klijn 2007; Wagenaar 2007). The main motives for involving stakeholders in decision making are to reduce the veto power of various societal actors by involving them in the decision making, to improve the quality of decision making by using information and solutions put forward by various actors and to bridge the perceived growing distance between citizens and elected politicians.

Previous research has shown that there is a tension between interactive governance and traditional governmental institutions. This creates difficulties for democratically embedding interactive governance (cf. Edelenbos 2005; Mayer et al. 2005; Klijn and Skelcher 2007; Sørenson and Torfing 2007). In practice, interactive governance and regular governmental decision-making processes live apart from each other with the result that the content developed in both trajectories often do not become connected. Values, opinions, and solutions from the interactive process do not have meaning in regular governmental decision-making processes and vice versa. There is a missing institutional link between the interactive process and the formal decision-making process; the interactive process is dissociated from the existing institutional environment causing oftentimes deadlocks in the process (Edelenbos and Monnikhof 2001).

Interactive governance is often organized as an informal process with particular rules and roles that are different from the existing institutional representative system and run parallel or prior to the formal institutions of negotiation and decision making (Edelenbos 2005). Stakeholders participating in the interactive process show dissatisfaction with and do not support decision making that does not recognize their values and priorities. As a consequence their support declines, which leads to deadlocks in the process. Therefore, it is important to make connections or interfaces between interactive governance and existing democratic institutions, in order to realize legitimate decision making. Flyvbjerg (1998, p. 235) argues that the question of how existing institutions can be utilized more democratically may be more pressing than the question of how to establish more democratic institutions as such. The problem lies in organizing the links between interactive governance initiatives and existing power structures in order for them to become meaningful.

The aim of this article is to gain knowledge about the possibilities or difficulties of connecting processes of interactive governance with existing (democratic) government institutions. We want to identify barriers to interfaces and investigate ways to overcome them. We want to do this by assessing the strength of certain types of interfaces between interactive governance and regular institutions of governmental decision making in a case study. Hence, this article is neither concerned with any postulated (liberal) democratic deficit of interactive governance (see, e.g., Sørenson 2002; Mayer et al. 2005; Sørenson and Torfing 2007), nor is it concerned with issues of representativeness, inclusion, or (in)equality in interactive processes. The main research question is: what are the 
possibilities and difficulties in creating interconnections between interactive governance and existing democratic institutions?

The case study presented in this article concerns an interactive project to redevelop a degrading area in the province of Zeeland, in the southwestern part of the Netherlands. Central to the project is the construction of a large water body, which is meant to create momentum for the development of housing, recreation, and nature. This case study was an experiment to explore the interconnections between the interactive process and existing democratic institutions.

The rest of the article is structured as follows. Section 2 deals with the background of this study. Section 3 sketches out the theoretical and analytical framework. The empirical observations are discussed in Sect. 4 and analyzed in Sect. 5. Some conclusions are presented in the sixth and final section.

\section{Background: Dutch interactive governance and water management}

This research project brings together interactive governance and water management. Traditionally, the Dutch domain of water management and water policy has been dominated by a technocratic approach springing from the engineers who shaped it. Water management was predominantly perceived as a matter of engineering and the primary goal was to increase the level of safety against floods. The last decade saw a shift in both the aim of water management and the role of (technocratic) institutions in this regard.

While the primary aim was to protect the low lands from the threat of seawater, it was increasingly recognized that rivers and the increasingly erratic discharge of water posed a threat similar to that posed by rising seawater levels. Consequently, much effort was, and continues to be, placed on providing extra room for the riverbed, e.g., through the realigning of dykes. As a result, water management and spatial planning became increasingly interconnected, extending the number and type of actors bearing a stake in water-related issues. This called for new ways of dealing with (controversial) stakes in decision-making processes.

In the Dutch situation, there have been calls for more direct forms of influence on policy-making since the 1970s. The change in participation began to take flight from the 1990 s onwards. Citizens and other social groups were not only organized according to formal participation mechanisms, but also through other forms of direct participation (cf. Wagenaar 2007). Considerable stakeholder involvement initiatives can also be observed, particularly at the levels of local and provincial government (Edelenbos and Monnikhof 2001), concerning water management and water in spatial organization consistent with international developments (e.g., Sabatier et al. 2005; Scholz and Stiftel 2005).

Interactive governance is defined here as the early involvement of all types of stakeholders (e.g., citizens, farmers, NGOs, and private companies) in the development, determination, and implementation of public policy (Edelenbos 2000). Participation enables stakeholders to negotiate with the government in the development and implementation of policy. While governments continue to play an important role in these activities, their traditional central position is no longer a given. The situation now is one in which civil servants and politicians, together with societal actors, negotiate the formulation of policy and its implementation. This occurs especially when it comes to spatial issues such as urban development and infrastructure development. Such issues are wicked problems, and interactive decision making and citizen participation are seen as methods to 
deal with this complexity. It is in this context that the project described in this article was able to materialize.

\section{Theoretical framework}

While governments often cherish their perceived independence and authority, the reality in Western Europe, but also outside this area, is that they are becoming increasingly aware that they are not capable of developing and implementing policies without support from and the contributions of others (Koppenjan and Klijn 2004). A complex web of (interdependent) relations between governments, businesses, NGOs, and civil society emerges as a result of this. Governments increasingly attempt to shape many types of alliances and cooperation models in order to deal with complex issues in the public domain (Rhodes 1997). The Netherlands is no exception to this type of development.

The relationship between representative and participative democracy

Much of the recent literature has questioned the effectiveness of representational democracy (McLaverty 2002; Sørenson and Torfing 2003, 2007). Some argue for the strengthening or even replacement of representational democracy with more direct forms of participation that fit into the complex interactive nature of many multi-facetted decisionmaking processes (Hirst 1997; McLaverty 2002; Sørenson and Torfing 2003).

Some view governance networks and interactive policy-making as representations of a renewal and revival of democracy: an injection of direct democracy in a decaying system of representation (c.f. Verweij and Josling 2003; King 2003). Others see it as a contribution to the (continuous) decline and hollowing-out of formal representative democracy: a further attack on the primacy of politics, democratic values, and the continued fragmentation of political decision making (c.f. Mayer et al. 2005). This concern stresses the democratic anchorage of governance networks and in particular interactive processes (Sørenson 2002). Regardless of the perspective, there is a clear tension between representative and participative democracy.

In the following sections, four interfaces are presented that have been developed and implemented in this research project. An interface is defined in this article as the arrangements that have been organized to interconnect or link government to governance processes. We distinguish four interfaces that are derived from the literature on governance networks and interactive governance. Below we elaborate these four interfaces. The first three interfaces, political, executive, and professional interfaces, represent linkages to certain actors in the governance network, politicians, executives, and professionals, which follows some scholars emphasizing that it is important to have sound contacts with other actors in the governance network (Meier and O'Toole 2001). The fourth interface is born from the gained insight from other research (Edelenbos 2005) to created policy embeddedness for interactive governance.

\section{Political interface}

The interface between processes of interactive governance has a political dimension to it. Some argue that the state is hollowed out and that politics are moving from Parliament and city councils to society and the market (c.f. Milward and Provan 2000). Others state that politicians continue to play a unique role in a representative democracy and have the 
authoritative power to decide in the end, i.e., the primacy of politics (cf. March and Olsen 1989; Koppenjan and Klijn 2004).

In the traditional representative democracy perspective, political officials attempt to control the government process, whereas in the participative democracy view they provide autonomy for stakeholders to govern themselves and take on a different role (cf. Sørenson 2006). In this meta-governance point of view, various forms of self-regulation are stressed (c.f. Jessop 1998; Kooiman 1993; Sørenson 2002, 2005; Sørenson and Torfing 2003, 2005).

The role of political officials in interactive governance processes depends on their views on democracy and their willingness to participate. If they hold their traditional role, they will remain at a distance from the interactive process (Edelenbos 2005). If they are willing to participate in interactive processes, they can take on more active roles. Sørenson (2002) distinguishes between four types of roles:

1. Hands-off framing of interactive governance: the shaping of the political, financial, and organizational context in which interactive governance takes place;

2. Hands-off story-telling: governance can be exercised through the construction of social and political meaning and identity;

3. Hands-on support and facilitation: politicians are in a direct way supportive and facilitative through their interactions with stakeholders, but not simply in a way to achieve their own objectives;

4. Hands-on participation: politicians work to influence the outcome of interactive governance through direct participation and deliberation in the interactive process.

\section{Executive interface}

When speaking about the institutional embedding of interactive governance, the executive level is also important. Interactive governance is in many ways always embedded in the existing administrative and executive institutions (Edelenbos 2005). We speak of executive embedding when a minister on the national government level or an alderman on the municipal government level plays an active role in the interactive process and is clearly committed to it through his or her tasks within the authority. This commitment can be expressed before, during, and after the interactive process (Klijn and Koppenjan 2000).

Earlier research has shown that the quality of the executive embedding is higher (a) the more the leaders champion the initiatives to promote citizen participation explicitly within the concerned policy-making process, (b) the more the leaders are committed to taking the contributions of the participants of the interactive process seriously when making policy decisions. This includes an obligation to identify why certain elements have or have not been included in the actual policy decision and (c) that he or she makes time and resources available for sorting through and implementing the results of the process (Edelenbos et al. 2009).

Healey (1997, p. 269) argues that policy principles have to pass 'formal places' in order to achieve administrative legitimacy. Flyvbjerg (1998) also argues that there is a tension between informal arenas and formal administrative arenas, when he discusses the Aalborg project in detail. He states that interactive governance (for which he uses the term 'rationality') is reshaped by existing administrative structures (for which he uses the term 'power'). Executives who stress their role from a government point of view (instead of from a governance point of view) are reluctant to commit themselves to the interactive process and therefore tend to remain at a safe distance from these processes. 
Professional interface

A third interface is that within the professional domain. Particularly in the field of water management and spatial development, policy-making and decision making is expert-driven and expert-produced according to technocratic standards (cf. DeSario and Langton 1986; Fischer 2000; Hisschemöller 1993). Technocracy is defined as the application of technical knowledge, expertise, techniques and methods to problem solving. This includes the belief that the desirability of the solution can be shown by standardized methods and technical procedures and that the use of available expert knowledge is sufficient for an efficient implementation of the solution. Consequently, the participation of stakeholders is superfluous because they do not have the necessary (technical) knowledge and expertise required to understand the problem and to come up with the appropriate solution.

There is, however, declining belief in the superiority of expert and scientific knowledge based on a positivistic ground (Fischer 2000), and a second, democratic type of decision making has now been introduced (DeSario and Langton 1986). This begins from the assumption that all those who are affected by a given decision have the right to participate in the making of that decision. This imposes new criteria on the decision-making process, such as the accessibility of the process, the responsiveness of the policy to those who are affected (inclusion) and openness (Macpherson 1979; March and Olson 1995; Scharpf 1997), rather than efficiency or rationality criteria of technocratic decision making.

In interactive processes, the expert is seen as one of the possible sources of knowledge. The process of knowledge production is a process of social construction in which different knowledge providers (experts and stakeholders) are active. Hence, experts play a different role in these kinds of processes compared to traditional approaches. They bring with them their specific knowledge and actively seek additional knowledge, context and are locally oriented (Rinaudo and Garin 2005). The worlds of experts and citizens are combined and interconnected (Woolgar 2000). This interconnection is stressed in, for instance, the literature on joint fact-finding (Ehrmann and Stinson 1999), participatory policy analysis, collaborative dialogs (Innes and Booher 1999), collaborative analysis (Busenberg 1999), and interactive social science (Caswill and Shove 2000).

\section{Policy interface}

Research has shown that, for interfacing between interactive governance and existing democratic institutions, it is important for the outcomes of interactive processes to be molded in the policy product specifications (Edelenbos and Monnikhof 2001). Moreover, the outcomes of the interactive governance processes must be within the substantive boundaries and conditions set prior to the start of the interactive process. These conditions are set by existing policy decisions or existing legislation and can be found in policy documents, white papers, etc. There are also process conditions to meet, such as time and deadlines. Overstepping these time constraints means that outcomes cannot be connected to the reality of procedures in the regular decision-making process.

Analytical framework and research methods

\section{Analytical framework}

In order to determine and evaluate the four identified interfaces between interactive governance processes and the existing institutional environment, in the operationalization 
of the four connection points or interfaces, a distinction is made between weak ( - ), moderate $( \pm)$, and strong $(+)$ interfaces (which refers to either activities or attitudes). By weak interface we mean that the interface is very light (or even absent) and that governance and government processes remain disconnected and that mutual coordination is absent. By moderate interface we mean that the interface is present but does not fully determine the connections between interactive process and governmental institutions. By strong interfaces we mean that government and governance processes are closely connected to each other, the activities in the governance process are coordinated with the government process and vice versa.

Through this operationalization we do not want to imply that the tighter connection is always the better. A very tight interface could lead to dominance over the governance process by the governmental track, a very loose interface on the other hand could lead to ignorance of the governance track by the government track. However, some form and degree of interface is needed, as argued in Sect. 1 of this article, but the desirable form and degree cannot be known beforehand; it depends on contextual and local conditions, which differs from case to case. In this article, we are interested in the possibilities and difficulties in organizing interfaces as such, and how the strength of the interfaces relates to the occurrence of deadlocks. In this way we try to find out which forms and degrees of interfacing could work out in connecting government to governance processes.

Below we operationalize the three categories in more detail for the four types of interfaces defined in the previous section.

- Political embedding:

- weak interface: politicians maintain a safe distance from the interactive process, and are only active when they have to control and assess the outcomes after the interactive process is completed;

- moderate interface: politicians set the framework and conditions for the interactive process, monitor the progress closely and assess the outcomes of the interactive process;

- strong interface: politicians follow the progress actively via for example direct participation (auditing and debating) in the process, and involve the results of interactive projects in the political decision-making process.

- Executive embedding:

- weak interface: executives are familiar with the interactive process and support the initiative, but do not participate in the interactive process;

- moderate interface: executives support the interactive process and are actively informed by civil servants about the progress;

- strong interface: executives are not only closely involved in organizing the interactive meetings, but also respond actively to questions and remarks made by participants.

- Professional embedding:

- weak interface: professionals are reluctant to actively get in touch with stakeholders, and do not treat stakeholder knowledge as a legitimate source of knowledge;

- moderate interface: professionals are willing to treat stakeholder knowledge as a source of knowledge (along with expert knowledge) but attempt to improve the feasibility of the plan from their expert point of view; 
- strong interface: professionals see lay knowledge as a legitimate source of knowledge, they are prepared to react to stakeholder input in a non-defensive manner, and are also willing to participate a joint fact-finding process.

- Policy embedding:

- weak interface: the existing policy decisions and product specifications relevant to the issue are not taken into account in the course of the interactive process;

- moderate interface: the existing policy decisions and product specifications are known, but are not decisive in presenting the results from the interactive process;

- strong interface: the existing policy decisions and product specifications are fully reckoned with, and determine the way in which the outcome of the interactive process is formulated and positioned.

The four interfaces were assessed at two moments in time during the process, half-way through the project (end of 2006) and at the end of the project (end of 2007), and the beginning of 2006 (start of project) was taken as the starting point (point of reference).

\section{Methods}

Empirical evidence for this case study was obtained from three sources. Firstly, the authors were independent academic project advisors in the project and as such were able to follow the process in great detail. This was done within the paradigm of action research methodology (Argyris et al. 1985). This means that the development and testing of the interfaces was conducted locally and continuously in the project as the researchers learned what worked well and what did not (cf. Elden and Levin 1991). The researchers were closely involved in the policy- making process in such a way that they were even a part of it. The researchers did not relate to their environment in an impersonal manner, but instead, were in constant interaction with the actors whom they were evaluating. Alkin (1990, p. 74) calls this "situated responsiveness." According to Greenwood and Levin (1998, pp. 75-76), action research has several features:

- it is context-bound and focused on practical problems;

- participants and researchers generate knowledge in mutual dialog and close interaction;

- they use the diversity of experiences and capacities in the group of investigated actors to enrich the research process;

- the images constructed in the research process lead to action, and the reflections may lead to the construction of new images;

- the reliability and validity of action research can be measured by seeing to what extent action, based on research, really resolves problems.

Action researchers in the domain of public decision making are clearly oriented toward assisting with the policy practice they investigate and making a contribution to its improvement together with the actors involved (Stringer 1996; Greenwood and Levin 1998; Wadsworth 2001, p. 52). The consequence of this is thus that the researchers are the subjects of their own research, and this is common in action research (cf. Greenwood and Levin 1998; Elden and Levin 1991). Researchers therefore need to constantly reflect on their actions, i.e., why they are doing things, how the research environment is responding and how they, in turn, have to respond to this reaction. 
Secondly, document analysis was carried out. This includes documents such as policy documents, scenario studies, and informal communications. Thirdly, interviews were conducted with all the people involved, a questionnaire was administered and an ex-post evaluation was carried out.

\section{Case description: research project 'Around Arnemuiden'}

\section{Background information}

The project Around Arnemuiden was aimed at developing a vision for the redevelopment of a rural area in the Zeeland delta (the Netherlands), northeast from Zeeland's main city of Middelburg. It consists of a village, Arnemuiden, and a number of polders that are used for agriculture. The north borders a major lake, called Lake Veere, and has some small-scale recreational functions. Much of its population has a background in fisheries or farming and is considered introverted or even hostile to new developments. In 1997, the village was annexed by Middelburg and since then, spatial planning has become a task for the municipal spatial planning department of Middelburg.

The area has a recent history of developing plans that could not be executed because local stakeholders obstructed their implementation. The 1998 publication of the 'Quality Atlas 2030', a future vision of a broader area, that placed substantive amounts of water in the area under consideration, and the development of a large scale housing project, was objected by the local stakeholders, drawing attention to their lack of involvement in the process. The local inhabitants preferred to maintain the area in its current rural state and rejected the proposed construction of new houses, as this would inevitably mean a change in the social structure of the village. Planning on this element of the Quality Atlas was postponed. However, the municipality continued to aim for a spatial change and housing development in the area. Meanwhile, a regional vision on the area had been in development: the regional vision 'Around lake Veere', presented in 2004. ${ }^{1}$ Concerning the area northeast of the village of Arnemuiden discussed above, again the construction of a large water body was proposed. This plan reinforced opposition, as again local stakeholders were not actively involved in the development of the plans except for having the opportunity to respond through a website.

An interactive process was set up in early 2006 to mediate between these opposing perspectives and to work toward developing a joint vision of the area. A consortium was formed consisting of relevant governmental parties and NGOs, ${ }^{2}$ and independent organizers of the process. ${ }^{3}$ Under the header 'Around Arnemuiden', this consortium aimed to develop a widely supported recommendation for the spatial redevelopment of the area outside the village of Arnemuiden. A strongly interactive character was seen as a way to escape the stalemate into which the process had gone. A recommendation for redevelopment of the area was presented to the city council of Middelburg in December 2007. This

\footnotetext{
1 This regional vision was developed by the provincial authorities of Zeeland, the municipality of Middelburg and surrounding municipalities, and several other authorities.

2 Involved were the municipality of Middelburg, the province of Zeeland, the local Water Board and Rijkswaterstaat (the Dutch water management organization), the farmers' organization, environmental organizations, and several other relevant parties.

3 TNO (Netherlands Organization for Applied Scientific Research), Tauw (Technical consultancy in water management), and EUR (Erasmus University Rotterdam).
} 
plan had strong public support, but it is the council that eventually decides on the realization of the plans.

Organizing and adjusting the interactive game

As previous developments in the area had resulted in obstructions and fierce debate, in our functions as action researchers and process managers, we decided to set up the interactive process in an open manner, enabling all parties or individuals who felt involved in the issue to participate. They were free to join in at any time and all products developed were freely accessible. In order to facilitate a process with that many parties and stakeholders, the participants were assigned to different groups, with each credited with their own role, task and responsibilities during the process (see Table 1).

The advisory group played a central role in developing the final recommendation for redevelopment of the area. Contrary to conventional planning procedures, the role of the experts was limited to a supporting position, which involved providing suggestions for improvement and improved feasibility, as well as answering questions from the advisory group.

The participatory process was set up in several stages; however, no strict format was used and the stages evolved as the process managers saw fit, overlapping and being actively adjusted and developed during the process itself. A brief and chronological description of the activities and events, as we experienced and documented it, is presented below.

Table 1 Participant groups in the process Around Arnemuiden

\begin{tabular}{|c|c|c|}
\hline Group & Members & Function \\
\hline $\begin{array}{l}\text { Advisory } \\
\text { group }\end{array}$ & $\begin{array}{l}\text { Actors with a direct stake in the development } \\
\text { area, both organized as well as non- } \\
\text { organized (citizens, farmers, associations, } \\
\text { companies, etc.). }\end{array}$ & $\begin{array}{l}\text { Formulation of a recommendation on the } \\
\text { spatial development of the area. }\end{array}$ \\
\hline $\begin{array}{l}\text { Expert } \\
\text { group }\end{array}$ & $\begin{array}{l}\text { Experts with a professional stake in the area, } \\
\text { with backgrounds varying from } \\
\text { consortium-organizations to interest groups } \\
\text { with expert knowledge. }\end{array}$ & $\begin{array}{l}\text { Assessing the ideas of the advice group and } \\
\text { contributing by providing suggestions } \\
\text { based on their own expertise. }\end{array}$ \\
\hline $\begin{array}{l}\text { Process } \\
\text { group }\end{array}$ & $\begin{array}{l}\text { Executives of the administration of } \\
\text { Middelburg, the province of Zeeland, the } \\
\text { regional department of water management, } \\
\text { TNO, Tauw, and EUR. }\end{array}$ & $\begin{array}{l}\text { Supporting the process by taking care of the } \\
\text { daily management. }\end{array}$ \\
\hline $\begin{array}{l}\text { Supervision } \\
\text { group }\end{array}$ & Representatives of the consortium members. & $\begin{array}{l}\text { Guiding the process through the political } \\
\text { level of decision making and deciding on } \\
\text { every next stage in the project. }\end{array}$ \\
\hline $\begin{array}{l}\text { Reflection } \\
\text { group }\end{array}$ & $\begin{array}{l}\text { Researchers, director of financing innovation } \\
\text { program }\end{array}$ & $\begin{array}{l}\text { Critically scrutinizing the innovative quality } \\
\text { of the process and providing the process } \\
\text { group with advice. }\end{array}$ \\
\hline $\begin{array}{l}\text { 'Public } \\
\text { stand' }\end{array}$ & $\begin{array}{l}\text { Everybody interested in listening to and } \\
\text { observing the process, from the general } \\
\text { public to the council of Middelburg and the } \\
\text { scientific community. }\end{array}$ & $\begin{array}{l}\text { Gives everybody interested the opportunity to } \\
\text { take notice of the process and be present at } \\
\text { meetings, without the consequences of } \\
\text { active involvement. These actors are } \\
\text { informed about the progress of the project. }\end{array}$ \\
\hline
\end{tabular}


Spring 2006: setting up the supervision group

At the beginning of the process, we invested due time and energy in setting up a group of representatives of the consortium members and motivating them to support the process aims and set-up. The provincial deputy and responsible alderman played an especially important role in this. After that, we invested time in developing a support plan for the upcoming process, establishing the playing field for the project, the process organization was set up (the positions and roles of different actors), existing policy documents and regulations were inventoried (identifying constraints and limitations), communication processes to relevant parties were organized and a time schedule for the project was designed.

During this stage, we found that the municipality in particular attempted to steer the process by imposing strict rules and restrictions that favored their own position. Also, the farmers' organization threatened to leave the consortium because they felt that they were positioned in a defensive role. After we paid due attention to their concerns and some adjustments were made, they were convinced to continue to participate.

\section{Spring-summer 2006: setting up participation}

We conducted 60 interviews with participants (stakeholders as well as experts), in order to assess the perceived strengths, weaknesses, threats, and opportunities of the area. From this we deduced rules and restrictions on future developments in the area, along with ambitions and 'dreams' as input for the next stage of scenario-development. In order to adapt to locally existing procedures and conventions, we actively involved a small informal group (district community group) in this process.

We concluded this stage with a report on the issues relevant to the area under consideration, which was accepted by the local actors, relevant expert organizations, and the consortium. This report acted as a starting point for cooperation among the parties involved and made it possible to treat the outcomes of the process in the regular decision-making processes. We organized a kick-off meeting, where expectations were addressed, the rules of the game were presented and politicians and the municipality were provided with the opportunity to express their commitment to the process.

\section{Summer 2006-fall 2007: development of scenarios for recommendation}

During the summer of 2006, we started developing scenarios for redevelopment of the area as foundations for a policy recommendation that would be reviewed and adjusted several times during the period following this. The advisory group first developed four broadly defined scenarios that exhibited the ideal future of the area, irrespective of financial, technical, or other constraints. It appeared to us that structural reframing had taken place during the process, for the four scenarios were quite alike although there appeared to have been major differences at the start. The main differences concerned the intensity of future changes. The scenarios were adjusted in light of expert suggestions and policy restrictions, after which all members of the advisory group valuated the scenarios. Based on this valuation, we selected a number of highly appreciated elements that the advisory group combined and reframed into two (rather than four) new scenarios during collaborative sessions. At a second meeting, experts reviewed these two new scenarios, identifying bottlenecks and suggesting improvements. Again the advisory group used these suggestions to adjust the scenarios. 
We functioned as mediators between the expert and advisory groups, keeping meetings of the groups separated. This enabled experts to prepare their answers, and information could be provided to the advisory group in advance, which prevented the advisory group from feeling as if they were not being taken seriously. Several experts doubted the righteousness of this deliberate separation, indicating difficulties with extending their traditional role and difficulties in getting their message across to the advisory group because of our intermediary role. The experts kept focusing on the financial aspects and technical deficits of the scenarios.

We noticed that the double role of the municipality in the process, not only in initiating the project as a member of the consortium, but also in bearing a stake in and assessing the outcome of the process, appeared to be problematic. The municipality could not communicate its goals univocally and appeared unable to act upon its different roles in the separate groups, which resulted in an ambiguous appearance. Even though the municipality approved of the process during the first stage, municipal participants doubted the feasibility and effectiveness of the project and reformulated goals during the process. Generally, the municipal administrators and executives stressed their representative democratic function, not tolerating any more direct forms of intervention. From this perspective, an appointed group such as the district administration group should not be empowered in the decisionmaking process.

\section{Winter 2007: development of the final recommendation}

The advisory group further specified the two scenarios, and during our last session all the participants in the advisory group agreed on the co-existence of two final plans and that both should be presented to the city council. In order to mold this recommendation into the current policy products, it was formulated as a part of the Quality Atlas. A representative of the advisory group presented the recommendation to the mayor of Middelburg in December 2007 during a celebratory meeting. As the recommendation is non-binding, the city council would now decide on the scenarios.

Preceding the final presentation, we organized three extra meetings with the expert group. In reaction to increasing demands of the municipality to clarify financial aspects of the scenarios, the experts discussed the expected costs and benefits of both scenarios. We attempted to guide them into a discussion on broader valuation considering different perspectives of the scenarios (Societal Cost-Benefit Analysis or SCBA), as a severely restricted financial paragraph would do no justice to the values and arguments of the citizens incorporated into the scenarios. Citizen's values and the financial values as measured by a financial planner were placed on par to each other during these sessions. However, the majority of experts protested against these methods of valuation. Some stated that the scenarios had to be compared on direct and short-term financial costs and benefits only, as this was common practice within the municipality. As a result, the expert group refused to implement the discussions on the SCBA in the report of their findings.

Nearing the time of the final presentation of the recommendations, many of the parties involved began to be nervous about the idea of having to speak out on the recommendations. Only a few days before the presentation, the farmers' organization withdrew from both the outcomes and the process. They sent a letter stating their concerns to the farmers and land owners in the area under consideration, who did not share this rejection because they felt responsible for the outcome due to their active involvement in developing the scenarios. The municipality became nervous about the connection between the interactive outcomes and the existing customs and conventions that were built on representative 
approaches, not knowing how to couple them and fearing that they would be compelled to come to unfavorable conclusions. Eventually, the politicians found a way to allow the recommendation into existing procedures. However, they avoided straightforward statements on the outcome and several experts distanced themselves from decisive statements on the scenarios, fearing that they would be held responsible. To date, the status of the recommendation remains unclear. There is talk that the municipality of Middelburg is preparing for a discussion of the recommendation in the city council. However, as the eventual decision making has already been postponed a few times (in 2008), it is feared that the recommendation will be put into cold storage, as a result of the politicians being unable to treat the interactive results within their representative practices. Silence currently surrounds the subject, illustrated by the removal of project documents from the municipal website and the absence of any communication with the participating stakeholders. Although our task has expired we are considering contacting the municipality to revive the project.

\section{Analysis of organizing the four interfaces}

This section discusses the organization of the four interfaces in the case of Around Arnemuiden. Our goals at the starting point are discussed, as well as the empirical observations and constraints at both the intermediate (end of 2006) and the final stage (end of 2007). Tables 2 and 3 summarize the main findings.

\section{Political interface}

We intended to involve the councilors in an active role. This would provide additional importance to the process and would allow for linkages between the regular decisionmaking processes and this interactive process. Based on earlier research (Edelenbos and Monnikhof 2001), we were prepared for the councilors' reluctance to participate in the interactive process. It was, however, the alderman and civil servants who rejected these plans because they would be contrary to the traditional function of the city council, i.e., to control the executive. From the perspective of representative democracy, there would be little possibility of providing the councilors with an active role in the interactive process. It would prevent them from performing their traditional role adequately. As a result, it was decided that the alderman responsible for spatial development would provide information to the council committee spatial development on a regular basis (initial weak interface; Table 2).

However, the idea of the involvement of the council in the advisory board was passed on to the political parties of Middelburg. Five councilors who wanted to attend the advisory group took up the role of auditor. This meant that the councilor would not actively participate in the debates and discussions but would observe these discussions, in order to understand the underlying arguments for the development of the scenarios ('public stand'; Table 1). They would also inform the council committee about the progress in the interactive process, especially in the advisory group. The council was especially interested in the aspect of house building in the designated area; they could keep an eye on this through the involvement of the five councilors. This explains the willingness of councilors to attend the governance process.

The direct role of the councilors paid off at the end of the project when the results were presented to the entire council. The chairman of the council committee for spatial 
Table 2 Interfaces: implementation and assessment (end 2006)

\begin{tabular}{|c|c|c|}
\hline Interface & Implementation & $\begin{array}{l}\text { Assessment strength interface } \\
\text { (weak, moderate, strong) }\end{array}$ \\
\hline 1. Political & $\begin{array}{l}\text { Reluctance on the part of executives and } \\
\text { civil servants to involve politicians: } \\
\text { politicians need room to fulfill their } \\
\text { controlling function. }\end{array}$ & Weak \\
\hline 2. Executive & $\begin{array}{l}\text { Involvement in guidance group. Much time } \\
\text { invested in getting the executives from the } \\
\text { province, national government } \\
\text { (Rijkswaterstaat), municipality, and water } \\
\text { board committed. }\end{array}$ & Strong \\
\hline 3. Professional & $\begin{array}{l}\text { Civil servants from the province, } \\
\text { municipality, and Rijkswaterstaat are } \\
\text { involved in the process group. } \\
\text { Professionals from the water board are } \\
\text { heard via interviews, but not yet actively } \\
\text { involved in the interactive process. }\end{array}$ & Moderate \\
\hline 4. Policy & $\begin{array}{l}\text { Setting preconditions. } \\
\text { Exploring prior and running policy } \\
\text { trajectories. } \\
\text { Setting up connection with Quality Atlas. }\end{array}$ & Strong \\
\hline
\end{tabular}

development expressed that the council would keep an eye on how the results would appear in the Quality Atlas policy document. The involvement of politicians in the interactive process functioned as a form of pressure on the executive and civil servants not to brush the results aside. While the alderman and civil servant preferred to keep the city council in a more passive role, the councilors themselves saw room for a role more comparable to the role of 'hands-on support' and even toward 'hands-on participation' (ultimately strong interface; Table 3).

\section{Executive interface}

Special attention was paid to the involvement of the executives in the project. At the beginning of the project, a supervision group was established. Its task was to monitor the project and to make changes to the project when they were deemed necessary. The executives of the public organizations involved participated in this group, which provided them with updates. In this way, we aimed to maintain the executives' commitment to the project.

Initially, the Province's deputy was an important person in mobilizing this supervision group. She was very enthusiastic about this project, and was a leading figure in this group. This active and enthusiastic involvement had a positive effect on the involvement of the municipality. The alderman at that time also became more and more interested in the project (initial strong interface, Table 2).

The local elections in 2006/2007, however, saw the instatement of a new alderman for spatial planning in the municipality. This meant that more time had to be invested in getting the new alderman involved. Similarly, the severe illness of an important top civil servant meant that his replacement had to be drawn into the project as he was unknown to the project. Executive embedding was challenged once again when the Province's deputy 
Table 3 Interfaces: implementation and assessment (end 2007)

\begin{tabular}{|c|c|c|}
\hline Interface & Implementation & $\begin{array}{l}\text { Assessment strength interface } \\
\text { (weak, moderate, strong) }\end{array}$ \\
\hline 1. Political & $\begin{array}{l}\text { Councilors are prepared to join the advisory } \\
\text { group (listening and framing) despite } \\
\text { reluctance at the executive level. } \\
\text { Providing feedback at council meetings. }\end{array}$ & Strong \\
\hline 2. Executive & $\begin{array}{l}\text { Involvement in the guidance group. Focus of } \\
\text { the municipality dominates in setting } \\
\text { goals and boundaries, as well as in } \\
\text { evaluation. } \\
\text { Provincial representative plays an important } \\
\text { supportive function. } \\
\text { (Electoral) Changes in representatives hinder } \\
\text { the process. Alderman is less committed. }\end{array}$ & Moderate \\
\hline 3. Professional & $\begin{array}{l}\text { Involvement in the process group and a } \\
\text { broader group of experts from relevant } \\
\text { organizations in the expert group (and } \\
\text { sub-groups). Experts stick to their } \\
\text { dominant and initiating role. Municipality } \\
\text { develops internal groups to press its own } \\
\text { goals. } \\
\text { A small group of committed experts, mainly } \\
\text { from the Water board and Rijkswaterstaat. }\end{array}$ & Weak \\
\hline 4. Policy & $\begin{array}{l}\text { Municipal formulation of detailed and fixed } \\
\text { boundaries attempting to reduce } \\
\text { uncertainty and unpredictability. } \\
\text { Eventual reserved attitude toward outcome, } \\
\text { weakening its status. } \\
\text { The status of the outcome of the interactive } \\
\text { process is degraded from an 'integral part' } \\
\text { of the Quality Atlas to 'use as input for' } \\
\text { this policy document. }\end{array}$ & Weak \\
\hline
\end{tabular}

had to leave after the Provincial elections and a new deputy arrived. This change, however, also provided room for the new alderman to commit himself more and to take on a stronger position as the project's advocate. However, the new people did not know and feel the history, occasion, and purpose of the project. A lot of time and attention had to be given to commit these new people to the project. A few newcomers still approached the project as an unwelcome inheritance.

Near the end of the project, when the outlines of the scenarios had been shaped, the executive embedding of the project became difficult to manage. The executives from the municipality, in particular, appeared reluctant to accept the interactive process and its output. Their perspectives dominated discussions on setting goals and boundaries and evaluation. Some people believed that they were only causing their own defeat if they could not fulfill the expectations of stakeholders during the decision-making process. This issue was discussed in a meeting of the supervision group under chairmanship of the new deputy of the province, who took a supportive position in the process. The alderman was pressured to take the scenarios seriously and to connect them with the Quality Atlas. Although he asked for more room to maneuver for the executive board and the city council, 
he stated that the scenarios would provide input for the Quality Atlas (see Sect. 5.4, policy interface). The members of the supervision group made a declaration in which this intention was formalized, expressing their embedding in the process. However, they did not explicitly initiate citizen initiatives themselves (ultimately moderate interface, Table 3).

The regional farmers' organization was recognized as an important partner but they repeatedly took a self-contained position during the process. During the initial phase they forced several conditions in the project documents, threatening to leave the supervision group if the conditions were not met. Even though their concerns were discussed in the supervision group, they declared that they did not feel as if they were taken seriously. Just before the project ended they withdrew from the group and the project's outcome. However, as this had happened before in the region, the other members of the supervision group were neither very concerned about this nor did they fear any consequences for the status of the outcome.

\section{Professional interface}

We aimed at the embedding of the process and its outcomes in the participating organizations through the establishment of an expert group. Rather than thinking out plans and presenting them to the political decision makers, as is the traditional role of experts, the participants in this group were meant to respond to questions from the advisory group regarding the possibilities and impossibilities of the plans. They were also asked to come up with alternative suggestions should some components of the proposals prove to be too complicated or impossible to build. In other words, the role of the experts shifted from an initiating role to a responsive role, which was expected to be difficult. By consulting them and by asking questions, the process managers hoped to connect the expertise of the experts with the process without having the experts turn down suggestions beforehand, and consequently hoped to tap into their resources to work on the plan before the city council had officially approved. Also, representatives of the municipality, province, and Rijkswaterstaat were joined together in a process group, taking care of the daily management of the process (see Table 1).

The expert group became active after a number of sessions of the advisory group had gathered enough questions for experts. This was done in order to allow the advisory group to develop its dreams before engaging in the process to make the plans feasible, because that step toward feasibility would inevitably mean decreasing freedom to dream about the future of the area. Thus, the expert group was confronted with an initial raw sketch of the two scenarios and was asked questions about the feasibility of the options. The expert group met 5 times in total. The first few meetings were dominated by municipal and provincial experts. There were also a number of meetings with a smaller group of experts concerning infrastructure and water exclusively. It remained difficult for the experts to alter their traditional role and to understand the valuation beyond merely making a shortterm cost-benefit analysis. They were skeptical about the ability of the advisory group to come up with a sound plan for the redevelopment of the area (initial moderate interface, see Table 2).

This feeling, however, quickly disappeared as the scenarios that emerged from the advisory group were deemed to be relatively logical. During later meetings, experts from the Water Board and Rijkswaterstaat became more actively involved and provided the process with more positive feedback. The experts insisted that, in order to realize the plans of the advisory group, considerable investments were necessary and that such funds were 
not readily available. Given the relative lack of financial means, they felt that the plans would probably never come to fruition and wanted the advisory groups to understand this.

Toward the end, it became clear that the experts regarded their task in the project as involving very different activities compared to the tasks they were usually assigned, so there was often little connection between this process and the internal tasks of the organizations. The indirect communication with the advisory group was experienced as troublesome and experts stuck to their traditional view that experts, rather than laymen, should initiate and develop plans. Within the municipality and more or less away from the process, internal groups were developed in an attempt to gain the upper hand in the process. The process group showed a similar dominance of municipal participants. Still, this group functioned well in its task to embed the municipality, Province and Rijkswaterstaat at the process level. Consequently, the embedding of professionals proved difficult, obstructing the connection of the process to representational democratic praxis (ultimately weak interface, Table 3). In general the professionals, mainly from the municipality, experienced the interactive approach as an attack on their own job and professionalism, explaining their reluctance in active participation in the interactive process.

There were two exceptions to the experts' reluctance. The experts of the Water Board developed a concrete plan to build a water body in the area and prepared a policy paper on this topic that was discussed with the Water Board's council in September 2007. Secondly, an inter-organizational working group, of which the municipality was a member, already existed that worked on a traffic plan for the area. This working group was willing to incorporate the plans into their traffic plan. However, as discussed earlier, the establishment of 10 internal working groups also illustrated the municipality's struggle to find a connection between the project and its internal routines. Each working group was another attempt at internal coordination but, in general, added to the municipality's feeling that the project created extra bureaucracy.

The findings of the experts were published in a document that was released. Initially, the municipality did not allow the document to be distributed among the public, but this was altered at a later stage and everyone was then free to view this information.

\section{Policy interface}

An extensive policy analysis was done prior to the start of the project, which included gathering relevant policy documents from the different governmental organizations. The aim was to identify conditions for the project from different (policy) perspectives. The analysis resulted in a reference scenario, i.e., a scenario that showed what would happen given all current policies and decisions but without any new changes. This scenario was used as a point of reference for the new scenarios. Also, the Quality Atlas was aligned and we communicated with the civil servants responsible for the Atlas. In this way, the results of the interactive process could be adjusted based on the Atlas' set-up and planning (initial strong interface, Table 2).

Setting the initial conditions sparked off considerable discussion. The municipality presented a long list of preconditions that had to be taken into account in an attempt to influence future outcomes. Upon closer examination, it was found that some conditions were actually wishes while other conditions were not as strict as we were made to believe. After lengthy discussions, a separation was made between hard and soft conditions. The hard conditions originated from legislation and policy lines that had passed through political decision making. In the end, only the hard conditions marked the playing field for the development of the scenarios. 
The preconditions became important again toward the end of the process. The municipality was especially afraid that not meeting the preconditions could lead to disappointment. At the same time, it was also used to weaken the obligation to agree with the scenarios and to implement them. The process group had to counteract this move and the scenarios were assessed explicitly with respect to the conditions. After brief discussion it became clear that all hard (and soft) conditions were met. However, financial feasibility remained a topic for discussion as the municipality insisted on short-term returns on investment.

The relationship with the Quality Atlas document was another theme within the policy embedding and was a much disputed subject within the municipality. The alderman indicated that the results of the interactive project would have to become a part of the Quality Atlas accordingly. Space was reserved to copy the results into the Atlas. However, the responsible civil servant held a different opinion. Discussion from within the municipality led to the conclusion that the scenarios would be 'related' to the Quality Atlas but would no longer be an integral part of it. After a fierce discussion in the supervision group on this retrenchment, the alderman assured them that the results would be strongly considered when drawing up the Quality Atlas. This was confirmed in the declaration of the executives in the supervision group (ultimately weak interface, Table 3). It turned out to be difficult to connect the internal procedure of making the Quality Atlas to the interactive process, because the municipal project leader and his team members did not want the fuzz and complexity coming from this interactive process. They wanted to design the Quality Atlas is isolation based on their own ambitions and professionalism.

Summing up our findings, it appeared that there was much resistance from certain parts of the governmental organizations to incorporate the results of the interactive process in their systems. The professional and policy interfaces in particular turned out to be weak. Although it was argued in Sect. 3 that the interconnection between interactive governance and regular governmental decision making is important, it is not easy to organize and maintain such a connection. Table 4 summarizes the strengths of the four interfaces at two points in time; the table also shows the developments in strength of these interfaces: a double minus symbolizes that it was degraded twice, a minus symbolizes being degraded once, a zero symbolizes the status quo, a plus symbolizes being upgraded once, and a double plus symbolizes being upgraded twice.

Table 4 makes clear that at the end of the project two interfaces, professional and policy, turned out to be weak. The executive interface was moderate, and only the political interface was strong. Overall the executive, professional, and policy interfaces became weaker in the course of the process, while the policy interface was degraded twice. Only the political interface became stronger during the process.

Table 4 Development of interfaces during the process

\begin{tabular}{|c|c|c|c|c|}
\hline Interface & Initial expectations & $\begin{array}{l}\text { Status at the end of } \\
2006\end{array}$ & $\begin{array}{l}\text { Status at the end of } \\
2007\end{array}$ & $\begin{array}{l}\text { Development during the } \\
\text { process }\end{array}$ \\
\hline Political & Difficult & Weak $(-)$ & Strong $(+)$ & ++ \\
\hline Executive & $\begin{array}{l}\text { Relatively } \\
\text { straightforward }\end{array}$ & Strong $(+)$ & Moderate $( \pm)$ & - \\
\hline Professional & Difficult & Moderate $( \pm)$ & Weak (-) & - \\
\hline Policy & Straightforward & Strong $(+)$ & Weak $(-)$ & -- \\
\hline
\end{tabular}


The professional interface turned out to be weak. The professionals (civil servants) and experts involved were very reserved toward the process, stressing their traditional roles and functions from a representative democratic point of view, and not tolerating any direct forms of intervention.

The policy interface also turned out to be weak. By demarcating the amount of room to maneuver for the interactive process, policy embedding was organized by identifying preconditions as soon as possible and by setting connections to existing policy products. The morphing of the preconditions indicated that the municipality used it as a means to steer the outcomes. Eventually, positions were reserved based on the relationship of the outcomes to existing policy products, thus weakening the position of the recommendation from the interactive process.

The political interface turned out to be strong, which came as a bit of a surprise. Based on earlier action research (Edelenbos and Monnikhof 2001), we expected that councilors would be very reluctant to participate in the interactive meetings. However, some councilors were prepared to fulfill the role of auditor in the advisory group. This more active involvement resulted in a rather strong connection, pressurizing other interfaces (executive) not to brush the results aside. The political embedding of the interactive process was apparently not related to the presence of a (strong) policy interface.

The executive interface was strong at first because the representatives of the province and the municipality were personally very committed to the interactive process, and carried their enthusiasm over to other executives. The initial enthusiasm collapsed as elections brought new people to the fore and the top civil servant had to be replaced due to illness. A strong political interface apparently did not lead to executive embedding of the interactive process itself.

\section{Conclusion and discussion}

This article has discussed and assessed the strength of interfaces between interactive governance and regular institutions of governmental decision making. One particular case was studied, Around Arnemuiden, a case in which regional spatial development (water, infrastructure, housing, nature, and environment) took place. Four interfaces were identified in order to organize this connection: political, executive, professional, and policy. Our findings indicate that the political interface grew stronger during the process whereas the strength of the policy interface diminished considerably. The executive and professional interface also diminished. It can therefore be concluded that overall, we did not succeed in organizing and maintaining the connection between the interactive process and the existing representative institutions of public decision making. In spite of our undertakings to firmly organize the four interfaces, the existing institutions (especially within the municipality) turned out to be very rigid and persistent so much so that it was challenging for them to adjust to the rules and roles in the interactive process. It was the policy and professional interfaces that prevented a connection between the outcomes of the interactive process and the existing ways of decision making from being forged. Clearly, professionals are not used too being led by citizens and entrepreneurs in developing policies (c.f. Rinaudo and Garin 2005). However, we did not witness a severe clash between direct and representative democracy: the auditing role of the councilors fit well with the controlling and monitoring role they normally play in the city council.

Altogether, our research shows that developing and maintaining connections is much easier said then done-not at least because initial expectations that lead to our approach 
did not always match the actual situation. Indeed, weak interfaces between government and governance lead to deadlocks in the interactive process, as was the case in our research.

We are fully aware that care must be taken in generalizing the insights from this case study as it is simply one case in one specific country, The Netherlands, and action research dictates that findings are local. Nevertheless, the case does provide an indication of how the interconnection can be made and when interfacing between interactive governance and regular governmental decision making is problematic and requires careful attention. The case study has shown that the problematic embedding of the interactive process lies with the professional and policy interface. This finding needs to be elaborated upon in further (international and comparative) research.

In reflecting on our work as action researchers and mediators between interactive processes and the existing institutional governmental environment, we recognize that:

- we began relatively late with the professional interface (compared to policy, executive, and political embedding) in April 2007. More time spent earlier in mobilizing and motivating experts could have strengthened this weak interface;

- we should have been more aware of the importance of positioning the results of the interactive process in the policy environment of the Quality Atlas (policy interface). The responsible civil servant should have been more involved and directly involved (by ourselves and not through the internal procedures and processes of the municipality). Also, more attention should have been paid to the departmentalization of the municipality, recognizing that the commitment of one civil servant does not in itself secure the track of the Quality Atlas;

- action research implies the investment of much time in generating support from different groups: the action researcher is a network manager, leaving little time for (scientific) reflection. This dilemma was solved by differentiating roles for different people: some were more oriented toward hands-on activities (mainly consultants), while others were focused on organization and reflection of the process (mainly scientists in the research group);

- even though we attempted to involve stakeholder and expert input (and knowledge) equally in the process up to the weighing stages of decision making, we recognize that we succeeded in this only to a certain extent. We were able to identify some constraints on such an approach, but this certainly is a subject that requires further experimentation and eventual institutionalization in order to be effectively executed in decision making.

The four interfaces presented in this article proved useful in organizing and analyzing the interconnection between interactive processes and regular institutions. In organizing interfaces between interactive processes and regular institutions of governmental decision making, our study has shown that the importance of policy and professional embedding in the process should not be neglected. The interfaces must be maintained constantly, especially when existing institutions approach interactive processes reluctantly. Experts and (municipal) civil servants, in this case, perceived the interactive process to be incompatible (or at best instrumental) to the existing system, undermining their legitimacy and decisionmaking powers. Strong political embedding did not settle this. Particularly in such cases, interfaces need to be organized very carefully and thoroughly, and above all, interfaces require constant reviewing and maintenance.

Open Access This article is distributed under the terms of the Creative Commons Attribution Noncommercial License which permits any noncommercial use, distribution, and reproduction in any medium, provided the original author(s) and source are credited. 


\section{References}

Agranoff, R., \& McGuire, M. (2003). Collaborative public management; new strategies for local governments. Washington, D.C.: Georgetown University Press.

Alkin, M. C. (1990). Debates on evaluation. London: Sage.

Argyris, C., Putnam, R., \& McLain Smith, D. (1985). Action science. San Francisco: Jossey-Bass.

Busenberg, G. J. (1999). Collaborative and adversarial analysis in environmental policy. Policy Sciences, 32, 1-11. doi:10.1023/A:1004414605851.

Castells, M. (2000, first edition 1996). The rise of the network society: Economy, society and culture. Cambridge: Blackwell Publishers.

Caswill, C., \& Shove, E. (2000). Introducing interactive social science. Science \& Public Policy, 27(3), 154157. doi:10.3152/147154300781781968.

DeSario, J., \& Langton, S. (1986). Citizen participation in public decision making. New York: Greenwood Press.

Edelenbos, J. (2000) Proces in vorm: procesbegeleiding van interactieve beleidsvorming over lokale ruimtelijke projecten. $\mathrm{PhD}$ thesis. Lemma, Utrecht.

Edelenbos, J. (2004). Political dimensions of interactive policy-making: New forms of interactive politics. In V. Bekkers (Ed.), Steering in the social sector (in Dutch) (pp. 10-26). The Hague: Kluwer.

Edelenbos, J. (2005). Institutional implications of interactive governance: Insights from Dutch practice. Governance: An international Journal of Policy Administration and Institutions, 18(1), 111-134.

Edelenbos, J., \& Klijn, E. H. (2007). Trust in complex decision-making networks: A theoretical and empirical exploration. Administration and Society, 39(1), 25-50.

Edelenbos, J., Klok, P-J, \& van Tatenhove, J. (2009). The institutional embedding of interactive policy making. Insights from a comparative research based on eight interactive projects in the Netherlands. The American Review of Public Administration, 39(2), 125-148.

Edelenbos, J., \& Monnikhof, R. (Eds.). (2001). Local interactive policy development. Utrecht: Lemma (in Dutch).

Ehrmann, J. R., \& Stinson, B. L. (1999). Joint fact-finding and the use of technical experts. In S. Susskind, S. McKearnan, \& J. Thomas-Larmer (Eds.), The consensus building handbook: A comprehensive guide to reaching agreement (pp. 375-400). Thousand Oaks: Sage.

Elden, M., \& Levin, M. (1991). Cogenerative learning. In W. F. Whyte (Ed.), Participatory action research (pp. 127-142). Newbury Park, CA: Sage.

Fischer, F. (2000). Citizens, experts and the environment. The politics of local knowledge. Durham: Duke University Press.

Flyvbjerg, B. (1998). Power \& rationality. Democracy in practice. Chicago and London: The University of Chicago Press.

Greenwood, D. J., \& Levin, M. (1998). Introduction to action research. Social research for social change. London: Sage.

Healey, P. (1997). Collaborative planning. Shaping places in fragmented societies. London: MacMillan.

Hirst, P. (1997). From statism to pluralism: Democracy, civil society and global politics. London: University College London Press.

Hisschemöller, M. (1993). De democratie van problemen. De relatie tussen de inhoud van beleidsproblemen en methoden van politieke besluitvorming. Amsterdam: VU Uitgeverij.

Innes, J. E., \& Booher, D. E. (1999). Consensus building and complex adaptive systems: A framework for evaluating collaborative planning. Journal of the American Planning Association, 65, 412-423. doi: 10.1080/01944369908976071.

Jessop, B. (1998). The rise of governance and the risk of failure. Oxford: Basil Blackwell.

King, L. A. (2003). Deliberation, legitimacy, and multilateral democracy. Governance, 16, 23-50. doi: 10.1111/1468-0491.t01-1-00203.

Klijn, E. H., \& Koppenjan, J. F. M. (2000). Public management and policy networks; foundations of a network approach to governance. Public Management, 2(2), 135-158. doi:10.1080/146166700411201.

Klijn, E. H., \& Skelcher, C. (2007). Democracy and governance networks: Compatible or not? Public Administration, 85(3), 587-609. doi:10.1111/j.1467-9299.2007.00662.x.

Kooiman, J. (Ed.). (1993). Modern governance: New government-society interactions. London: Sage.

Koppenjan, J. F. M., \& Klijn, E.-H. (2004). Managing uncertainties in networks: A network approach to problem solving and decision making. London: Routledge.

Lowndes, V., Pratchet, L., \& Stoker, G. (2001). Trends in public participation: Part 1 local government perspectives. Public Administration, 76(2), 205-222. doi:10.1111/1467-9299.00253.

MacPherson, C. (1979). The life and times of liberal democracy. Oxford: Oxford University Press. 
March, J. G., \& Olsen, J. P. (1989). Rediscovering institutions. The organizational basis of politics. New York: Free Press.

March, J. G., \& Olsen, J. P. (1995). Democratic governance. New York: Free Press.

Mayer, I., Edelenbos, J., \& Monnikhof, R. (2005). Interactive policy development: Undermining or sustaining democracy. Public Administration, 83(1), 179-199.

McLaverty, P. (Ed.). (2002). Public participation and innovations in community governance. Ashgate: Aldershot.

Meier, K. J., \& O’Toole, L. J. (2001). Managerial strategies and behaviour in networks: A model with evidence from U.S. public education. Journal of Public Administration and Theory, 3(11), 271-293.

Milward, H., \& Provan, K. G. (2000). Governing the hollow state. Journal of Public Administration: Research and Theory, 10(2), 359-379.

Rhodes, R. A. W. (1997). Understanding government. Buckingham: Open University Press.

Rinaudo, J. D., \& Garin, P. (2005). The benefits of combining lay and expert input for water-management planning at the watershed level. Water Policy, 7, 279-293.

Sabatier, P. A., Focht, W., Lubell, M., Trachtenberg, Z., Vedlitz, A., \& Matlock, M. (Eds.). (2005). Swimming upstream. Collaborative approaches to watershed management. Cambridge: MIT Press.

Scharpf, F. W. (1997). Games real actors play; actor centered institutionalism in policy research. Boulder (Co): Westview Press.

Scholz, J. T., \& Stiftel, B. (Eds.) (2005). Adaptive governance and water conflict. New institutions for collaborative planning. Washington: Resources for the future.

Sørenson, E. (2002). Democratic theory and network governance. Administrative Theory and Praxis, 24(4), $693-720$.

Sørenson, E. (2005). Metagovernance: The changing role of politicians in processes of democratic governance. The American Review of Public Administration, 36(1), 98-114. doi:10.1177/027507 4005282584 .

Sørenson, E. (2006). Metagovernance: The changing role of politicians in processes of democratic governance. The American Review of Public Administration, 36(1), 98-114. doi:10.1177/027507 4005282584.

Sørenson, E., \& Torfing, J. (2003). Network politics, political capital and democracy. International Journal of Public Administration, 26(6), 609-634. doi:10.1081/PAD-120019238.

Sørenson, E., \& Torfing, J. (2005). The democratic anchorage of network governance. Scandinavian Political Studies, 28(3), 195-218. doi:10.1111/j.1467-9477.2005.00129.x.

Sørenson, E., \& Torfing, J. (Eds.). (2007). Theories of democratic network governance. New York: Palgrave MacMillan.

Stringer, E. T. (1996). Action research. A handbook for practitioners. London: Sage Publications.

Verweij, M., \& Josling, T. E. (2003). Special issue: Deliberately democratizing multilateral organization. Governance, 16, 1-21. doi:10.1111/1468-0491.t01-1-00202.

Wadsworth, Y. (2001). Becoming responsive-and some consequences for evaluation as dialogue across distance. New Directions for Evaluation, 92, 45-58. doi:10.1002/ev.34.

Wagenaar, H. (2007). Governance, complexity, and democratic participation: How citizens and public officials harness the complexities of neighborhood decline. The American Review of Public Administration, 37(1), 17-50. doi:10.1177/0275074006296208.

Woolgar, S. (2000). Social basis of interactive social science. Science \& Public Policy, 27(3), 165-173. doi: $10.3152 / 147154300781782039$. 